\title{
O Zé Pereira em Rio Novo: uma manifestação cultural centenária no interior de Minas Gerais (1906-2006)
}

The Zé Pereira in Rio Novo: a century old cultural manifestation in the interior of Minas Gerais (1906-2006)

Felipe Araujo Xavier *

\begin{abstract}
Resumo
Este texto tem como escopo retratar a história de uma das manifestações culturais mais tradicionais do interior da Zona da Mata mineira, o Zé Pereira, bloco pré-carnavalesco que permanece ativo na pequena cidade de Rio Novo-MG há mais de 100 anos e tornou-se o primeiro "patrimônio imaterial" ou "intangível" registrado do município. Para atingir esse objetivo, apresento uma análise concreta e particularizada das transformações ocorridas nessa manifestação pré-carnavalesca, retratando as discussões sobre suas origens remotas, as quais remetem ao início do século $\mathrm{XX}$, sua relação com os "Clubes Carnavalescos" rionovenses, em um contexto de extrema segregação social e racial entre os cidadãos, sua emancipação na década de 1950 como um bloco autônomo e a continuidade dessa manifestação cultural, comemorando o seu centenário em 2006, quando foram reiniciados os debates sobre a sua origem e sua história. Para realizar este estudo, utilizo referências jornalísticas, documentos referentes ao bloco pré-carnavalesco e registros e depoimentos de foliões que participaram dos desfiles nas ruas de Rio Novo, seguindo um rigor metodológico relativo ao uso das memórias como fontes históricas.
\end{abstract}

Palavras-chave: Zé Pereira; Rio Novo; Carnaval.

\begin{abstract}
This paper aims to present the history of the one the most traditional cultural manifestations of the interior of Zona da Mata of Minas Gerais, the Zé Pereira the pre-carnival block which remains in activity in the small city of Rio Novo-MG for over a hundred years and became the first "immaterial heritage" or "intangible" registered in the city. In order to achieve this objective, I present a concrete and particular analyses about the transformations that occurred in this pre-carnivalesque manifestation, portraying the discussions about his remote origins that referring the begin of the twentieth century, his relations with the rionovenses "Carnival Clubs", in a context of severe social and racial segregation between the rionovenses citizens, his emancipation during the 1950s as an autonomous carnival block and the continuity of this cultural manifestation which became the most traditional of Rio Novo, which celebrated his centennial in 2006, when restarts the debates about the his origins and history. Then, as the basis to carry out this study, I use journalistic references, documents relating to the pre-carnivalesque block, along with records and testimony of merrymakers that participated in parades in Rio Novo streets, following a rigorous methodology for the use the memories as historical sources.
\end{abstract}

Keywords: Zé-pereira; Rio Novo; Carnival.

\footnotetext{
* Doutorado em História pela Universidade Federal de Juiz de Fora (UFJF).
}

Recebido em julho de 2016 | Aprovado em fevereiro de 2017. 


\section{Introdução}

No final do século XVIII, expedições chegavam ao interior da Zona da Mata mineira na ânsia de reconhecer os caminhos proibidos, averiguar a possível existência de metais ou pedras preciosas nessa região de tribos e áreas ainda desconhecidas. Assim, davam-se os primeiros passos para a formação do povoamento de Nossa Senhora da Conceição do Rio Novo.

Com o tempo ocorreu a chegada dos posseiros, as sesmarias foram sendo distribuídas e a terra habitada pelos desbravadores. A capela conseguira a Provisão Eclesiástica e, em 1834, foi executado o primeiro Plano de Arruamento do Arraial de Nossa Senhora da Conceição do Rio Novo (CARMO, 2006).

Em 1850, o povoado transformou-se em distrito e, no ano de 1870, foi elevado oficialmente à condição de município, transformando-se em sede de uma das poucas Comarcas da Província de Minas Gerais (FUNDAÇÃO CHICO BOTICÁRIO, 1951). ${ }^{1}$

Além de Comarca, aquele pequeno município também tornou-se um núcleo de festejos carnavalescos da região, mesmo sendo composta por uma sociedade na qual poucos gozavam de um bom padrão de vida e muitos sofriam com a pobreza e uma organização social extremamente segregante, em que os negros foram marginalizados e muitos alocados na outra margem do rio Novo, na área onde ficou conhecida como "Arraial dos Crioulos".

Apesar de carente, a população da pequena urbe entusiasmava-se com a comemoração do Carnaval, festejo que era anunciado pelo zabumbar dos zé-pereiras, manifestação de origem portuguesa que ganhou destaque entre os folguedos da capital Rio de Janeiro, chegando também até a pequenina Rio Novo.

Quando selecionei os zé-pereiras de Rio Novo como tema de estudo, me deparei com o fato de ser essa uma pesquisa inédita e atípica, já que os estudos acadêmicos voltados para as festividades, normalmente, tomam como temática ou base de reflexão as folganças dos grandes centros, com destaque para o carnaval carioca.

Assim ocorreu em clássicos como Carnavais malandros e heróis: para uma sociologia do dilema brasileiro, de Roberto Da Matta (1981, p. 30), que privilegia o carnaval como uma das bases essenciais de estudo do "povo brasileiro" o qual, em seu entendimento, encontra-se tão rebaixado nas interações pessoais e "tão sem voz, junto a uma elite tão rouca de gritar por suas prerrogativas".

\footnotetext{
${ }^{1}$ FUNDAÇÃO CHICO BOTICÁRIO. Jornais. Formação Administrativa. O Anuário d'A Gazeta, Rio Novo, dez. 1951.
} 
Foi recorrente em produções historiográficas brasileiras abordar o carnaval carioca, como na obra A subversão pelo riso: estudos sobre o carnaval carioca da Belle Époque ao tempo de Vargas, de Rachel Soihet (1998), a qual apresentou uma leitura do carnaval por meio das relações "circulares" entre a "cultura popular" e a "cultura dominante", a partir do modelo explicativo de M. Bakhtin.

Entretanto, nesses estudos historiográficos, destaco a visão de Maria Clementina Pereira da Cunha (2002), uma das principais revisionistas do tema "Carnaval" na historiografia brasileira, a qual propõe uma renovação na forma de leitura e interpretação da história social das festas, pregando uma maior proximidade dos estudos com os sujeitos históricos e das dimensões singulares das sociedades cujas celebrações produziram-se, captando o "dia, hora, lugar, sujeitos vários e predicados transitórios, significados mutantes e (inevitavelmente) polissêmicos, capazes de expressar a mudança e o movimento" (CUNHA, 2002, p. 12).

A partir do diálogo com obras tão distintas e distantes, nasce a pergunta: Por que estudar os zé-pereiras de uma cidade de proporções tão pequenas, entre 1906 e 2006 ? Essa questão talvez seja o foco primordial da pesquisa, pois ao entrar nas singularidades desse folguedo, não somente refuto as visões que apresentam uma imagem homogeneizada das festividades em busca de uma "teoria geral da festa", como também chamo a atenção para as especificidades dessa manifestação nas suas particularidades, reforçando uma leitura das folganças festivas como manifestações culturais polissêmicas e ressignificadas no seu espaço e tempo.

Além da atipicidade da temática, o contexto no qual essas pesquisas foram sendo desenvolvidas fez florescer outra problemática particular: a importância de preservar e manter o centenário bloco do Zé Pereira para a identidade e a cultura da cidade de Rio Novo.

Essa questão impulsionou o projeto de registro do Zé Pereira como o primeiro e, ainda hoje, o único "patrimônio imaterial" ou "intangível” rionovense, e o debate sobre a importância do resgate da memória e da história desse tradicional bloco que cativa e orgulha grande parte da população da cidade.

Hoje, o centenário bloco do Zé Pereira é sem dúvida a manifestação cultural mais antiga da cidade e goza de considerável participação popular, seja no posicionamento de espectador, seja de participante ativo nos desfiles pitorescos do bloco. 
O empenho na organização recebe grande energia de jovens rionovenses e da família Freitas, herdeira da tradição que veio passando de geração em geração, desde o desfile realizado pelo português Baltazar Germano ainda na primeira década do século $\mathrm{XX}$.

Além dessa colaboração, o folguedo também manteve-se por meio de doações ao seu Livro de Ouro e investimentos da administração municipal, a qual começou a ser mais pressionada após o registro do Zé Pereira como "patrimônio imaterial" ou “intangível”, em 2012, e o recebimento do ICMS cultural.

Dessa maneira, movido pela relação afetiva pessoal em relação à manifestação cultural e com o intuito de fortalecê-la e dar maior voz ativa aos rionovenses na reivindicação de suportes para o bloco junto às autoridades públicas, surgiu a ideia de registrar o bloco centenário como "patrimônio imaterial” ou "intangível” de Rio Novo, para que este gerasse a arrecadação do ICMS cultural e as autoridades tomassem consciência da importância do Zé Pereira para a identidade rionovense, o entretenimento e o turismo da cidade.

Hoje, mesmo tendo a possibilidade de relocar os rendimentos gerados pelo ICMS cultural, a administração tem um fundo direcionado para o Conselho Municipal de Patrimônio Cultural e o débito ético-moral com a população que continua a reivindicar a realização, preservação e permanência dos desfiles do Zé Pereira antes e durante o carnaval.

Não obstante, uma estratégia como esta de salvaguardar sem engessar uma manifestação cultural como a do Zé Pereira pôde ser realizada somente perante o alvorecer do recente debate sobre o registro do "patrimônio imaterial" ou "intangível", o qual carrega consigo o objetivo de expandir as políticas públicas de preservação do patrimônio cultural para além dos tombamentos dos bens móveis e imóveis.

Como Maria Cecília Londres Fonseca (2003) salientou, por mais de setenta anos as políticas patrimoniais construíram uma imagem do "patrimônio histórico" ligada aos conjuntos de monumentos e artes preservados pela excepcionalidade ou pela sua importância em eventos históricos, tornando-se, muitas vezes, desconectados da real diversidade e das tensões e conflitos simbólicos característicos da produção cultural brasileira.

Além disso, essas políticas centradas nos tombamentos - apesar de terem colaborado para resguardar e restaurar obras de arte e edificações - alimentaram demasiadamente a ideia de imutabilidade como forma de conservação, desqualificando 
a noção de mudança e transformação inerente aos significados aos quais são atribuídos aos patrimônios culturais.

Dessa maneira, a problemática levantada pelos debates sobre "patrimônio imaterial" ou "intangível" apareceu para ampliar a noção de patrimônio histórico e artístico, abordando os conteúdos de caráter simbólico, que compõem a formação de uma identidade cultural e respeitam os preceitos de uma sociedade que se quer construir democraticamente (FONSECA, 2003).

Entretanto, quando abrimos para um debate sobre o "patrimônio imaterial" ou "intangível” não nos referimos à preservação de meras abstrações em contraposição a bens materiais, pois qualquer tipo de comunicação necessita de algum suporte físico.

Assim, ao tratarmos da categoria de "patrimônio imaterial" ou "intangível", a imaterialidade é relativa, mas a mudança é intrínseca. Por isso, talvez seja mais propício utilizar o termo "patrimônio intangível", pois remete ao transitório e fugaz que não se materializa em algo durável e estático (FONSECA, 2003).

Nesse sentido, este estudo histórico-cultural entende o Zé Pereira rionovense como uma manifestação cultural dinâmica, vivida e atualizada socialmente pelos novos códigos os quais vão sendo agregados e reinterpretados. E para captar essas transformações utilizo jornais, documentos, fotos e principalmente os depoimentos de foliões de outrora.

Tendo as lembranças como fonte histórica, é necessário ressaltar que essas recordações não formam a memória em si, mas a reconstituição subjetiva de uma determinada experiência a partir da reminiscência.

O depoente, no processo de rememoração, tece uma teia entre as vivências compondo uma estrutura narrativa, a qual se reorganiza a cada ato de relembrar, e esse enredo está passível de interferências do presente e dos filtros pessoais (FERNANDES, 2001). Entretanto, como afirmou Henry Rousso, mesmo sendo um exercício psíquico individual de reconstituição do passado, a organização da memória está inserida no seu contexto social, tendo sempre seu caráter coletivo significativo (ROUSSO, 2002).

A lembrança é edificada com base nos materiais disponíveis na consciência presente e por mais que o exercício de relembrar procure ser exato, as imagens refeitas serão diferentes das experiências pretéritas. Portanto, o depoente não é o mesmo quando relembra um caso referente ao seu passado. Sua percepção e interpretação dos episódios modificaram-se no decorrer do amadurecimento individual, alterando suas leituras sobre o ocorrido (BOSI, 1994, p. 18). 
Fatos que não impedem de resgatar o passado por intermédio dos indícios das representações que as lembranças dos foliões de outrora deixam para nós sobre o Zé Pereira de Rio Novo, manifestação cultural cuja identidade dos cidadãos rionovenses fez-se permear.

\section{Os zé-pereiras do Rio de Janeiro a Rio Novo: suas origens, histórias, similaridades e singularidades}

No Rio de Janeiro, os zé-pereiras eram uma das folganças em meio às brincadeiras do entrudo. Armados com seus bumbos a esmurrar, eles ritmavam os demais foliões fantasiados com suas bisnagas prontas para travarem um jogo de molhadelas (CUNHA, 2001).

Diversos folcloristas e memorialistas abordaram a inserção do Zé Pereira no carnaval brasileiro. Dentre esses, o bibliotecário do Instituto Histórico Geográfico Brasileiro, Vieira Fazenda, o qual se destacou por ter sido o primeiro a mencionar o ingresso do Zé Pereira nos folguedos cariocas, em seu livro de 1904, Antiqualhas e memórias do Rio de Janeiro.

Numa perspectiva em que se buscava a purificação do folguedo, o escritor retratou a aparição do Zé Pereira em meados do século XIX, com um "modesto artista sapateiro, pacato burguês" português, de nome José Nogueira de Azevedo Paredes, o qual teria se equipado com um bumbo e desfilado nas ruas a zabumbar. Os foliões avulsos, perplexos com a invenção, juntaram-se a ele em meio à brincadeira e deram vivas ao "Zé Pereira” e não ao "Zé Nogueira” (FAZENDA, 1940, p. 327-328).

Outro importante memorialista a retratar o surgimento do Zé Pereira foi Luís Edmundo, autor da obra O Rio de Janeiro do meu tempo. Reforçando a perspectiva de Vieira Fazenda, reafirmou que o Zé Pereira teria origens lusitanas, sendo trazido pelo mesmo sapateiro da Rua São José, o qual, segundo Luís Edmundo (2003) teria aperfeiçoado suas batidas no bumbo com o exercício de golpear as solas dos sapatos.

Dotado de uma visão preconceituosa típica dos escritores do século XIX, ávidos por civilizar a população foliona, refere-se ao carnaval carioca como uma manifestação festiva ligada à plebe e sua rudez desalinhada, na qual a balburdia reinava e descreve um Zé Pereira de 1852, composto por sete ou oito "plebeus", empunhados de tambores, bumbos e caixas de rufo, passando nas ruas a surrar estupidamente seus instrumentos. 
A princípio, o Zé Pereira é um préstito de fragoroso alarido. Batecum. Estrondear de pelicas. Berraria caótica e hiperacústica de sons loucos, de brados, loucos, de barulheira louca. Não se canta. De resto, as palavras não seriam ouvidas, ante o ensurdecedor e reboante conflito de estrondos e retumbos que a fúria de braços vigorosos arranca, violentamente, ao oco das caixas, dos bombos e tambores. (EDMUNDO, 2003, p. 476).

Em sua perspectiva, esse uso descomedido dos instrumentos de percussão não seria à toa, pois, para Edmundo, quando um homem da elite é venturoso expressa-se com o sorriso, já o plebeu necessita dos ruídos e das gargalhadas para exteriorizarem suas alegrias (EDMUNDO, 2003).

Visões como essas foram corriqueiramente utilizadas pelas elites cariocas, as quais ao assistirem os desfiles dos zé-pereiras, reforçavam suas críticas aos cortejos cada vez mais comuns nas ruas do Rio de Janeiro no século XIX.

A historiadora Maria Clementina Pereira Cunha, em seu livro Ecos da Folia: uma história social do carnaval carioca entre 1880 e 1920, descreve o mal-estar gerado por essa plebe "desclassificada" a zabumbar nos carnavais cariocas. Segunda a autora, os zé-pereiras com seus bumbos e caixas rufando deram ritmo às danças dos mascarados avulsos, unindo e deixando-os ainda mais ameaçadores. Ali, naquelas aglomerações de foliões poderiam ser encontradas as figuras mais distintas e perigosas para as elites. Eram os negros e brancos pobres, vadios, prostitutas, trabalhadores braçais ocupando um mesmo espaço, o qual, na concepção das elites letradas, era um local promíscuo e contagioso, capaz de colocar em risco a ordem social almejada.

Embora a imagem do Zé Pereira remetesse a um "costume de sujeitos sem costumes" ou aos habitantes dos cortiços, as sociedades carnavalescas foram inserindo paulatinamente o folguedo em seus festejos (CUNHA, 2001). Bem diferentes dos zépereiras habitados pelos capoeiras, as seletas agremiações carnavalescas promoviam seus zé-pereiras dentro do modelo civilizado, o qual desejavam implantar aos demais setores sociais.

Com o tempo, os zé-pereiras, aos poucos reformulados, ganhavam as graças das elites. Nas grandes sociedades, nos bailes e bairros elegantes esses tipos de folguedos difundiram-se (CUNHA, 2001).

Em Rio Novo, o Zé Pereira também fez parte do repertório das brincadeiras carnavalescas e a descrição de sua origem é controversa. Duas são as principais versões sobre o princípio do folguedo na cidade mineira. 
Uma delas é apresentada pelas memórias de alguns integrantes do Club Explosivos Carnavalescos, os quais, como Maria Aparecida Pinto Duarte ${ }^{2}$, defendem que o folguedo teria iniciado com o clube no carnaval de $1907^{3}$; já a segunda versão, que se popularizou pela cidade, afirma que essa folgança originou-se, antes mesmo da fundação dos Explosivos, em um dia de carnaval no qual o português Germano Baltazar, junto com alguns amigos, estavam em um bar bebendo, quando tiveram a ideia de pegarem um carro de boi e panelas para saírem batendo pelas ruas rionovenses, promovendo o Zé Pereira.

Essa segunda versão tornou-se mais popular e difundida por meios de comunicações e pela equipe de organização do bloco, reafirmando sempre a relação entre Zé Pereira e a família do português Capitão Germano Baltazar. Sendo assim, a manifestação teria sido iniciada com Germano Baltazar, seu filho José Vieira de Freitas (1895-1995) - conhecido como Senhor Juquita - que teria mantido o bloco por boa parte do século XX, com a ajuda de seu sobrinho Nelson Paes e, posteriormente, já na década de 1990, passado a administração para Lauro Rooke (sobrinho de Nelson Paes) e logo depois para um grupo de jovens o qual teria na diretoria a presença de netos e bisnetos de Nelson Paes e do Senhor Juquita. Portanto, não mencionam ligação alguma com os tradicionais clubes carnavalescos da cidade.

Mas para deixar ainda mais complexa essa relação entre a fundação do Zé Pereira, Carmelita Betonte Mattos ${ }^{4}$, a ex-presidente do Club Explosivos Carnavalescos, reorganiza sua memória combinando as duas versões. Segundo a depoente, o bloco teria sua origem ligada aos Explosivos, mas sob a administração de Nelson Paes e Senhor Juquita $^{5}$.

\footnotetext{
${ }^{2}$ Tendo formação de professora e primeira vereadora de Rio Novo, Maria da Conceição Pinto Duarte nasceu em 1920 e frequentou o salão do Club dos Explosivos Carnavalescos assiduamente durante as décadas de 1930 e 1940, quando participou do Bloco das Turmalinas, um bloco feminino dos Explosivos. Foi engajada no Clube da Terceira Idade, onde foi fundadora e presidente, promovendo o Bloco da Terceira Idade nas noites de carnaval.

${ }^{3}$ Essa versão comete um pequeno erro de anacronismo ao afirmar que o Zé Pereira teria surgido em 1907, junto ao clube dos Explosivos Carnavalesco, já que a fundação da agremiação teria ocorrido em março de 1907, um mês após o carnaval daquele ano. Assim, sua participação no carnaval de Rio Novo teria ocorrido somente em 1908. Cf. Maria da Conceição Pinto Duarte. Entrevistada por Felipe Araujo Xavier e André Colombo, nov. 2004.

${ }^{4}$ Amiga de Maria da Conceição Pinto Duarte, Carmelita Betonte Mattos foi frequentadora dos Explosivos Carnavalescos, participou do Bloco das Turmalinas e chegou a se tornar presidente do clube na década de 1960. Também participou do Clube da Terceira Idade e do seu bloco.

${ }^{5}$ Carmelita Betonte Mattos. Entrevistada por Felipe Araujo Xavier e André Colombo, jan. 2005.
} 
Seja qual for a versão mais adequada para dar os louros da fundação da manifestação cultural que se tornou a mais popular da cidade, é necessário frisar que tanto a primeira representação quanto a segunda podem ser pertinentes, pois está em jogo o próprio entendimento sobre a pluralidade de significados atribuídos ao Zé Pereira, nos diversos locais e momentos históricos.

A versão da família Freitas, a qual ganhou status de "oficial", apesar de suas especificidades, está bem próxima do modelo apresentado pelos festejos populares portugueses inseridos nas ruas do Rio de Janeiro, com seus foliões surrando instrumentos improvisados, como panelas, latas e bumbos, em que se encontravam os mais diversos personagens como os diabos, pierrôs, capoeiras, etc.

Realmente existe uma referência indireta sobre a presença do Zé Pereira em Rio Novo, antes mesmo da fundação dos Explosivos. O jornal O Rio Novo do ano de 1907, no qual havia uma seção de matérias denominada "Farpinhas", retratou em uma poesia a presença do Zé Pereira e seu alarde tipicamente pré-carnavalesco da seguinte maneira: "Já na rua o zé-pereira / Faz algazarra infernal / Assim por esta maneira / Se annuncia o carnaval. / Assim não haja desgosto; / Que se não faça arrelia; / A polícia no seu posto. / Deixe passar a folia!" (FUNDAÇÃO CHICO BOTICÁRIO, 1907, p. 1). ${ }^{6}$

Porém, essa questão não elimina a participação dos Explosivos na reordenação do evento, ou na fundação de um novo bloco, pois aquele Zé Pereira, com seu diabo, carro de boi e suas latas e panelas desapareceu ou foi remodelado com sua inserção na agremiação. Nos Explosivos surgiu um Zé Pereira com uma nova roupagem, na qual trazia consigo uma banda com seus instrumentos de sopro, não se limitando aos bumbos e às caixas rufando ou às panelas e latas batendo. Também seriam inseridos fogos de lágrima, lanternas, a bandeira e o estandarte das agremiações, etc.

No ano seguinte, em 1908, o mesmo periódico noticiava que o Zé Pereira abrira o carnaval e divulgava a expectativa em torno do grande evento preparado pelos Explosivos Carnavalescos.

Promete animação e muita folia o carnaval deste anno, organizado pelo Club Explosivos Carnavalescos, sociedade animada e cheia de enthusiasmo desta cidade. Já se ouve o zé-pereira todas as noites, sempre animado e cada vez mais forte. (FUNDAÇÃO CHICO BOTICÁRIO, 1908). ${ }^{7}$

\footnotetext{
${ }^{6}$ FUNDAÇÃO CHICO BOTICÁRIO. Jornais. Farpinhas. O Rio Novo, Rio Novo, 3 fev. 1907. p. 1.

${ }^{7}$ FUNDAÇÃO CHICO BOTICÁRIO. Jornais. Carnaval. O Rio Novo, Rio Novo, 26 jan. 1908.
} 
Diante de tal apresentação ficou a dúvida: Este Zé Pereira já estava ligado ou não aos folguedos promovidos pela agremiação?

Tudo leva a crer que o bloco referido na fonte acima também foi promovido pelos Explosivos e daí em diante, outros zé-pereiras foram sendo noticiados como folganças ligadas aos clubes carnavalescos que surgiram no transcorrer dos anos e, somente na década de 1970, a manifestação cultural é apresentada pela imprensa como independente das agremiações carnavalescas e único da cidade (FUNDAÇÃO CHICO BOTICÁRIO, 1979, p. 1). ${ }^{8}$

\section{Os zé-pereiras e os clubes carnavalescos de Rio Novo}

Em uma sociedade marcada pela segregação, o carnaval de clubes de Rio Novo não foi diferente. O Club Explosivos Carnavalescos, fundado em 1907, tinha como frequentadores foliões com perfil popular, concentrando a classe trabalhadora da cidade, entretanto, excluíam os negros ${ }^{9}$. O Club Renitentes Carnavalescos - descendentes do Club dos Paladinos Carnavalescos - surgiu em 1925 e foi formado pelos coronéis, fazendeiros, altos funcionários do Estado e comerciantes mais ricos da cidade, grupos os quais compunham a elite rionovense. O Club Colar de Pérolas foi organizado na década de 1920 e frequentado pelos negros que compunham a parcela mais pobre da população. Já o Clube Carnavalesco O Nosso É Outro, criado em 1932, se caracterizou pelo combate à segregação, aceitando os mais distintos foliões, sem uma seleção preestabelecida com base na cor da pele, riqueza ou status.

Referências documentais demonstram como essas sociedades carnavalescas rionovenses inseriram os zé-pereiras na lista de seus folguedos. Sempre com caráter précarnavalesco, esses clubes botavam seus cortejos zabumbando e anunciando a aproximação do carnaval.

Muitas vezes, esses préstitos já começavam seus desfiles três meses antes do Reinado de Momo, preparando "[...] o carnaval em Rio Novo, que animava o carnaval da cidade era o Zé Pereira. Porque o Zé Pereira começava a sair em dezembro,

\footnotetext{
${ }^{8}$ FUNDAÇÃO CHICO BOTICÁRIO. Jornais. Salve a Alegria! Viva o Carnaval. A Gazeta, Rio Novo, 24 fev. 1979. p. 1.

${ }^{9}$ Maria da Conceição Pinto Duarte descreve: "classe média mesmo, mais popular", "era operário, professor", e para diferenciar a elite descreve: "Renitente era a classe alta, ali só tinha os coronéis, os fazendeiros, que frequentava ali." Cf. Maria da Conceição Pinto Duarte. Entrevistada por Felipe Araujo Xavier e André Colombo, jul. 2005.
} 
entendeu, todo o fim de semana o Zé Pereira saía, ele era pré-carnavalesco", afirma Maria Pinto ${ }^{10}$.

No mês de dezembro de 1925, o Club Renitentes Carnavalescos veio promover seu primeiro Zé Pereira: "Em dias da semana passada, após a solene assembleia que voltara o carnaval para 1926, esse valoroso club (dos Renitentes) improvisou tonitruante zé-pereira que sacudiu de alegria a cidade" (FUNDAÇÃO CHICO BOTICÁRIO, 1925). ${ }^{11}$

Anos depois, também constato referências de zé-pereiras promovidos pelo Club Colar de Pérolas. Com as Violetas do Colar ${ }^{12}$ regendo as canções pronunciadas pelos foliões, esse Zé Pereira teria percorrido as principais ruas da cidade proclamando a aproximação do Reinado do Momo de 1933 (FUNDAÇÃO CHICO BOTICÁRIO, 1933). ${ }^{13}$

Não obstante, a manifestação do Zé Pereira não ficou limitada à promoção dessas seletas e organizadas agremiações. Lauro Rooke ${ }^{14}$ diz ter participado, em sua juventude, de outro Zé Pereira o qual não era e não se assemelhava a nenhum desses até aqui representados.

Segundo o depoente, havia outras personalidades a promoverem os zé-pereiras de maneira diferente daqueles polidos préstitos apresentados pelos clubes. Eram mais parecidos com os barulhentos cortejos cuja principal característica era levar a folia e a algazarra nas ruas da cidade, abrindo espaço para os jovens promoverem suas travessuras ${ }^{15}$. Como ressaltou o jornal A Gazeta, "O Zabumba impera de verdade em todos os redutos multicores, onde a D. Sorumbática jamais teve guarida". (FUNDAÇÃO CHICO BOTICÁRIO, 1946, p. 1) ${ }^{16}$.

\footnotetext{
${ }^{10}$ Maria da Conceição Pinto Duarte. Entrevistada por Felipe Araujo Xavier e André Colombo, jul. 2005.

${ }^{11}$ FUNDAÇÃO CHICO BOTICÁRIO. Jornais. Renitentes. O Paládio, Rio Novo, 27 dez. 1925.

${ }^{12}$ Bloco composto por moças que frequentavam o Club Carnavalesco Colar de Pérolas.

${ }^{13}$ FUNDAÇÃO CHICO BOTICÁRIO. Jornais. Carnaval. Gazeta Rionovense, Rio Novo, 29 jan. 1933.

${ }^{14}$ Sobrinho de Nelson Paes, seguiu os passos do tio na arte de produzir as máscaras de papel machê e os bonecos gigantes do Zé Pereira. Chegou a ser presidente do Bloco nos anos de 1990, mas por falta de incentivo deixou o folguedo.

${ }^{15}$ Lauro Rooke. Entrevistado por Felipe Araujo Xavier e André Colombo, jan. 2004.

${ }^{16}$ FUNDAÇÃO CHICO BOTICÁRIO. Jornais. Carnaval. A cidade está inteiramente tomada por intensa alegria. A Gazeta, Rio Novo, 2 mar. 1946. p.1.
} 
Eu devia ter uns 12 anos de idade, mais ou menos, nessa época. Sou de 1939. [...] Saía o pessoal batendo prato, o Dr. Aristóteles ${ }^{17}$ junto batendo prato, a gente fazia umas baquetas. Virou uma bagunça total no começo, porque a gente saía lá de onde é o museu Chico Boticário. Não é qualquer pessoa que se lembra disso. Juntávamos o esterco de carro de boi. [...] A gente jogava uns estercos, os moleques jogavam um no outro, pra acertar o chapéu do Dr. Aristóteles. Ele parava e dava aquela bronca e o pessoal ficava parado, como se não fosse nós e aí saía de novo, aquela bagunça. ${ }^{18}$

Entretanto, dentre os diversos tipos de zé-pereiras promovidos no carnaval rionovense, é necessário reconhecer o destaque atingido pelo Zé Pereira do popular Explosivos Carnavalescos, tanto nas reconstituições das memórias dos foliões, quanto nas representações construídas pelos periódicos.

Segundo Carlos Fonseca da Costa ${ }^{19}$, nos Explosivos, os zé-pereiras começavam desfilar três meses antes do carnaval, fazendo "dois zé-pereiras por semana. [...] Pegava fogo. Os Explosivos faziam a quinta e o sábado, domingo tinha a domingueira, né!?”

Nesse clube, a folgança do Zé Pereira tomou uma dada proporção que, assim como a produção das fantasias, a organização dos blocos e cordões do clube e o enfeite do salão, sua coordenação também eram de responsabilidade de uma delegação formada pelos representantes dos Explosivos.

Em um periódico anual dos Explosivos Carnavalescos, O Explosivo, os eventos promovidos pela agremiação de 1928 foram registrados e, em meio às referências dos folguedos, o anuário apresentou os responsáveis pelo Zé Pereira e descreveu a composição do cortejo.

Entre seus organizadores dirigentes encontramos os nomes dos senhores Emilio Serpa, o qual seria o chefe dos seus auxiliares, Waldemiro Vaspesiano e Antônio Peroni. Já a descrição desse bloco foi concebida pelo O Explosivo da seguinte maneira:

\begin{abstract}
Abria o Zé-Pereira duas grandes letras E.C em lanterna, iniciais gloriosas dos "baêtas". A seguir vinha outra magnífica lanterna, bem idealizada e na qual si acham colocados 32 lanternas pequenas e era empunhada pelo consócio José Coelho. O zé-pereira empunhava-se de 120 lanternas e teve o estupendo concurso das Turmalinas, que entoaram a marcha "Venham velhas" letra de lord Pin-Pin e música do maestro Repinpim. Outro formidaloso zabumba realizou-se a 12 do corrente, tento as Turmalinas cantado o samba Sapo, Sapinho. Letra e música de Ary Kerner. Nesse zabumba o chefe da comissão
\end{abstract}

\footnotetext{
${ }^{17}$ Aristóteles Câmara Leal Paixão foi conhecido pela alcunha de Tote Paixão, filho de Antônio Jacob da Paixão, um dos Constituintes de 1881, foi advogado e o primeiro diretor do jornal O Paládio.

${ }^{18}$ Lauro Rooke. Entrevistado por Felipe Araujo Xavier e André Colombo, jan. 2004.

19 Nascido na segunda década do século XX, Carlos Fonseca participou dos festejos dos Explosivos Carnavalescos. Foi porta-bandeira do clube nos diversos blocos promovidos pela agremiação e vivenciou de perto os desfiles dos zé-pereiras durante longa data. Cf. Carlos Fonseca da Costa. Entrevistado por Felipe Araujo Xavier e Mazoel Magalhães Fonseca, mai. 2008.
} 
armou um carrinho alegórico, com troféus do ano passado, representando em seu trono o nosso majestoso Leão. Ao terminar esse zé-pereira, realizou-se na sede dos "baêtas" um animado baile à fantasia, cuja concorrência foi extraordinária e distinta, prolongando-se até às duas horas. (FUNDAÇÃO CHICO BOTICÁRIO, 1928, p. 1). ${ }^{20}$

Dotada de uma rica descrição do folguedo, as recordações de Maria Pinto retratam um modelo de ordenação do Zé Pereira, com semelhanças à maneira relatada acima pelo anuário. Segundo a depoente, esse bloco sempre era arranjado com alas, as quais seguiam uma sequência aparelhada:

\begin{abstract}
$\mathrm{Na}$ frente saía a molecada carregando lanternas, as lanternas eram todas muito coloridas, todas feitas de papel de seda, muito bonitas, eram redondas, quadradas, elas tinham vários feitios. Saía aquela turma, era uma ala de uns quarenta moleques; já tinha aquela turma que todo ano saía com as lanternas. Depois vinham as Turmalinas, depois os bonecos do Zé Pereira e atrás a banda de música, era assim que funcionava o Zé Pereira. Os fantasiados podiam comparecer atrás da banda de música. ${ }^{21}$
\end{abstract}

Além dessas alas, o Zé Pereira era dotado do estandarte e da bandeira do clube. O porta-bandeira mais tradicional foi Carlos Fonseca da Costa, o Senhor Carlinhos, que relembra dos desfiles ao relatar a multidão que esperava para assistir o Zé Pereira no Largo da Igreja Matriz. Segundo o depoente, a aglomeração de pessoas era tamanha que para dar passagem ao bloco, era necessário rodar a bandeira e ganhar o espaço da rua para conduzir tranquilamente o desfile do cortejo. ${ }^{22}$

Sua esposa, Josélia Tavares da Fonseca ${ }^{23}$, reforça essas lembranças, afirmando que "Zé Pereira era todo mundo com lanternas de luz acesa." ${ }^{24}$ Assim como Dona Carmelita, a qual se lembra da confecção artesanal dessas lanternas feitas pelos próprios sócios do clube. Segundo a depoente,

\footnotetext{
${ }^{20}$ FUNDAÇÃO CHICO BOTICÁRIO. Jornais. Os Zé Pereiras. O Explosivo, Rio Novo, 8 mar. 1928. p. 1.

${ }^{21}$ Maria da Conceição Pinto Duarte. Entrevistada por Felipe Araujo Xavier e André Colombo, nov. 2004.

${ }^{22}$ Carlos Fonseca da Costa. Entrevistado por Felipe Araujo Xavier e Mazoel Magalhães Fonseca, mai. 2008.

${ }^{23}$ É necessário ressaltar que Josélia, como é conhecida por todos, foi registrada oficialmente como Josina Tavares da Fonseca, mas seu nome é desconhecido pela maioria da população rionovense e a mesma preferia ser chamada de Josélia. Portanto, utilizaremos no corpo do texto o nome o qual se tornou referência à sua pessoa. Por sua vez, Josélia Tavares da Fonseca participou dos Explosivos aproximadamente nas décadas de 1930 e 1940, quando fez parte do Bloco das Turmalinas por vezes.

${ }^{24}$ Josina Tavares da Fonseca. Entrevistada por Felipe Araujo Xavier e Mazoel Magalhães Fonseca, mai. 2008 .
} 
[...] os Explosivos saía, e numa fila e na outra, os jovens participava com a gente. Saía de lanterna. Você não chegou a lembrar, ver lanterna de bambu? Pega o bambu, conta o gomo assim, amarra o arame assim e amarra em cima e coloca papel de seda, o nosso era vermelho e preto, e põe uma vela acesa. Aquilo vai iluminando aonde o bloco vai e aquele foguete lá vindo atrás. ${ }^{25}$

Seguindo os meninos e suas lanternas vinham o Bloco das Turmalinas, organizado internamente pelos Explosivos. Esse bloco tinha participação presente nos mais diversos eventos da agremiação e no Zé Pereira não era diferente.

Segundo Maria Pinto, referindo aos anos de 30 e 40,

[...] quem participava do Zé Pereira eram as Turmalinas, que era um bloco do clube. Saíamos todas fantasiadas, se o carnaval era daquele ano saíamos com as fantasias do ano anterior, era o bloco das Turmalinas que animava esse Zé Pereira. ${ }^{26}$

Com suas fantasias, vinham em coro apresentando as marchas as quais seriam cantadas no carnaval e as próprias marchas produzidas pelos músicos dos Explosivos Carnavalescos.

Logo após vinham os bonecos gigantes e os foliões fantasiados. Sempre respeitando a ordem, a ala das lanternas, as turmalinas, os fantasiados misturavam-se aos bonecos gigantes, cuja supremacia era visível nos desfiles com a imponência de suas estruturas.

Em meio a essa multidão de foliões fantasiados, muitos vestiam suas máscaras para tornarem-se irreconhecíveis aos demais participantes e promoverem suas saudáveis brincadeiras dentro do bloco. Nas memórias de Maria Pinto resgato a participação, por exemplo, de Nelson Paes no Zé Pereira dos Explosivos, cuja habilidade de produção artesanal de máscaras de papel machê o deu a aptidão de produzir suas monstruosas fantasias.

[...] até o Nelson Paes era muito engraçado, ele fazia umas fantasias muito interessantes para o Zé Pereira. Tinha muita gente que fantasiava e você não conhecia, não sabia quem era, usavam máscaras, muitas máscaras no Zé Pereira. As pessoas que entravam no carnaval, e que não queriam ser reconhecidas, faziam máscaras muito engraçadas. Eu me lembro que a Paulina falava assim: "Ai meu Deus, todo mundo fantasia para ficar bonito, o Nelson só fantasia para ficar mais feio". Ele fazia cada máscara horrorosa. ${ }^{27}$

\footnotetext{
${ }^{25}$ Carmelita Betonte Mattos. Entrevistada por Felipe Araujo Xavier e André Colombo, ago. 2005.

${ }^{26}$ Maria da Conceição Pinto Duarte. Entrevistada por Felipe Araujo Xavier e André Colombo, nov. 2004.

${ }^{27}$ Maria da Conceição Pinto Duarte. Entrevistada por Felipe Araujo Xavier e André Colombo, nov. 2004.
} 
Essa "ala" seria o local aberto aos demais foliões, sejam eles de outros clubes ou não. Portanto, o Zé Pereira dos Explosivos apresentava-se como uma manifestação précarnavalesca com o atributo de aglutinar os diversos personagens rionovenses, não implantando a correspondente separação dos grupos sociais encontrada nos dias de carnaval.

Todo mundo que quisesse acompanhar entrava, não tinha disso não. No Zé Pereira, depois que a gente saía vinha branco, vinha dos Renitentes, vinha do Colar, vinha de todo mundo, aí entrava todo mundo e dançava, brincava, ensaiava e pronto. ${ }^{28}$

Mesmo dotado desse espírito de união, todos os foliões deveriam seguir códigos de conduta inseridos no folguedo. Havia uma ordem a ser preservada e seguida e os representantes do clube não descuidavam do trabalho de vigiar e respaldar a organização da folgança.

\begin{abstract}
Podia participar outras pessoas, mas teriam que ir lá combinar: "Oh nós vamos sair." "De que vocês vão sair?" A não tem problema não. Mas tinha que obedecer uma disciplina, não é todo mundo chegando. Não era vem quem quer, não. Entrava sim, entrava com ordem. "O senhor Wilson, nós queremos entrar com uma fantasia." "Não tem problema". Mas já sabia, fulano vai participar, aí podia, mas fora disso não. Era a turma dos Explosivos é que tinha o privilégio de sair no Zé Pereira. Agora outras pessoas poderiam entrar desde que obedecessem aquela ordem, aquela disciplina, mas chegar lá entrando, não entrava mesmo. ${ }^{29}$
\end{abstract}

Conhecer a identidade dos foliões permitia controlá-los, visto que escondiam seus rostos atrás das máscaras. Todavia, numa cidade na qual o número de habitantes girava em torno de quatro a seis mil, muitas vezes, era necessário apenas saber como o folião sairia fantasiado para registrar em consciência quem eram os mascarados, sendo possível vigiá-los, caso indispensável.

Diante de toda essa preocupação com o polimento da conduta dos foliões, a quebra da ordem tornava-se uma ocorrência não muito corriqueira dentro dos dias de Zé Pereira. Com a força policial dando apoio aos desfiles, os sócios do clube cuidando dos foliões e do modelo de conduta e o respeito disseminado entre os foliões rionovenses, os participantes raramente rescindiam essas regras comportamentais. A depoente Maria Pinto segue reforçando suas lembranças sobre a ordem na folgança:

\footnotetext{
${ }^{28}$ Maria da Conceição Pinto Duarte. Entrevistada por Felipe Araujo Xavier e André Colombo, nov. 2004.

${ }^{29}$ Maria da Conceição Pinto Duarte. Entrevistada por Felipe Araujo Xavier e André Colombo, nov. 2004.
} 
Ninguém invadia o nosso Zé Pereira. Jamais alguém passou na frente dos meninos que estavam com as lanternas e no meio das Turmalinas, jamais! O povo vinha atrás da banda de música, ninguém desrespeitava o nosso Zé Pereira. Nunca houve uma invasão no nosso Zé Pereira. Aquilo era uma tradição, um bloco muito bem feito e muito respeitado, ninguém invadia. ${ }^{30}$

Carmelita reforça essas lembranças também reconstruindo um Zé Pereira organizado, no qual todos brincavam de maneira educada, sem distinção de cor ou grupo social. Além disso, também resgata a importância da participação do corpo policial na manutenção da ordem nos desfiles do bloco.

\begin{abstract}
Ah o Zé Pereira não tinha escolha, não. Todo mundo brincava. O que quisesse brincar, brincava. Mas aí brincava direito, não tinha nada, a polícia daqui olhava muito, mas muito mesmo, os presidentes em cima, é presidente, secretária ajudava, o Senhor Juquita não deixava, não! Mas corria tudo bem, tudo bem mesmo. ${ }^{31}$
\end{abstract}

Apesar de todo o polimento comportamental, esse Zé Pereira não deixava de ser um bloco tipicamente caricato e cômico. Seus desfiles apresentavam-se como um espaço para que os foliões, com suas fantasias, dirigissem suas críticas e ironias aos fatos ocorridos no cotidiano rionovense. Isso deixava as famílias em situação de tensão, pois todos tornavam-se alvos em potencial da ridicularização natural dessa manifestação pré-carnavalesca.

A finalidade do Zé Pereira era de nos divertir e nós tínhamos um presidente, Senhor Wilson de Oliveira [início dos anos de 1930], que era uma pessoa muito inteligente, que anotava todos os fatos pitorescos que acontecia em Rio Novo durante o ano, para depois fazer uma brincadeira sobre estes fatos no Zé Pereira. ${ }^{32}$

Esses atos burlescos eram uma das importantes brincadeiras inseridas nesse bloco caricato. O jornal O Explosivo também faz menção a um desfile de 1928, no qual foi produzido um carro alegórico para exaltar os feitos do clube no ano anterior, "com troféus do ano passado, representando em seu trono o nosso majestoso Leão", cujo objetivo era representar a vitória dos Explosivos no carnaval. Como não havia critérios para um verdadeiro concurso entre os clubes carnavalescos da cidade, o objetivo claro

\footnotetext{
${ }^{30}$ Maria da Conceição Pinto Duarte. Entrevistada por Felipe Araujo Xavier e André Colombo, nov. 2004.

${ }^{31}$ Carmelita Betonte Mattos. Entrevistada por Felipe Araujo Xavier e André Colombo, jan. 2005.

${ }^{32}$ Maria da Conceição Pinto Duarte. Entrevistada por Felipe Araujo Xavier e André Colombo, nov. 2004.
} 
seria a autoglorificação para alfinetar os rivais (FUNDAÇÃO CHICO BOTICÁRIO, 1928, p. 1). ${ }^{33}$

Senhor Carlinhos relembra uma ocasião na qual teria se incumbido de abrir uma placa para os rivais ao passar com o préstito na frente da sede dos Renitentes. Quando executou o prometido, todos depararam com a seguinte frase "Tão grande e tão bobo", mensagem a qual remetia tanto à opulência dos Renitentes, local de sociabilidade das elites rionovenses, quanto à resposta às chacotas as quais seus foliões manifestavam quando os Explosivos passavam em frente do seu prédio.

Porque nós passávamos lá e eles ficavam tudo na janelinha lá, rindo, vendo
nós... O presidente, quando foi no outro domingo, ele arrumou uma placa aí:
"Quando você chegar quase na hora você vira a placa". Eu lembro que eu não
tinha visto a placa, não. Tirei o papel assim: "Tão grande e tão bobo". Eles
estavam lá em cima nos Renitentes. [risos].

A rivalidade entre os clubes era uma prática muito comum durante o carnaval rionovense e essas reminiscências demonstram que, já no período que antecedia o reinado do Momo, os ânimos acalentavam-se.

O ex-presidente dos Renitentes, Benjamim Pavel (1965, p. 108), registrou em seu trabalho memorialístico Besta de Sela a presença dos zé-pereiras da década de 1920 como uma espécie de charanga a qual percorria as ruas da cidade, promovendo uma algazarra com seus tambores de latas.

Sem diferenciar essas manifestações ensurdecedoras dos polidos zé-pereiras promovidos pelos clubes, relembra o problema que poderia ser gerado caso dois zépereiras de sociedades diferentes se encontrassem nas ruas, tudo pelo fato da intensa rivalidade que as agremiações carnavalescas cultivavam em suas relações de disputas simbólicas.

Além disso, o memorialista ressalta a troça promovida pelos zé-pereiras de Rio Novo em relação à paródia "Zé Pereira Carnavalesco", da peça de Francisco Correa Vasques $^{35}$. Segundo Manuel Pavel, a irreverente canção, já nos anos de 1920, era a

\footnotetext{
${ }^{33}$ FUNDAÇÃO CHICO BOTICÁRIO. Jornais. Os Zé Pereiras. O Explosivo, Rio Novo, 8 mar. 1928. p. 1.

${ }^{34}$ Carlos Fonseca da Costa. Entrevistado por Felipe Araujo Xavier e Mazoel Magalhães Fonseca, mai. 2008.

35 A famosa peça teatral "O Zé Pereira carnavalesco", do ano de 1869, teve como autor o ator e dramaturgo Francisco Correa Vasques, mestiço, de origem modesta, abolicionista, cronista e integrante das rodas boêmias do Rio de Janeiro na segunda metade do século XIX. Segundo Maria Clementina Cunha (2002, p. 375; 379), nesse teatro foi parodiada a peça "Pompiers de Nanterre" - canção francesa de sucesso na França, encenada na corte francesa, pouco tempo antes da peça de Vasquez - construindo uma
} 
seguinte: "Viva o Zé Pereira / Atrás da bananeira / Comeu muita banana / E ficou de caganeira". (PAVEL, 1965, p. 107).

Essa canção habitaria o imaginário rionovense, chegando aos dias atuais, sendo incomparavelmente mais conhecida na cidade do que a original cantiga do "Zé Pereira Carnavalesco": "Viva o Zé Pereira / Que a ninguém faz mal / Viva a bebedeira / Nos dias de carnaval”.

Tal referência deixa claro o contato entre os carnavais da antiga capital e o de Rio Novo, reforçando a relação de ressignificação do modelo apresentado pelos cariocas. Nem mesmo a paródia que o dramaturgo Vasques fez da canção francesa ficou fora da releitura dos foliões rionovenses.

O Zé Pereira de Vasques, apresentado como o plebeu, beberrão e inofensivo, distinta da imagem dos perigosos grupos de zé-pereiras típicos do carnaval carioca, em Rio Novo, dá lugar a uma figura momesca "Senhor da gula", o qual, ao se empanturrar de banana às escondidas, é assolado por uma forte diarreia.

Nos seus desfiles, muitas marchinhas eram cantadas, tanto de artistas consagrados pelas rádios, quanto das canções produzidas pelos músicos da Euterpe Rionovense, uma instituição independente, mas sempre presente nos festejos dos Explosivos.

Assim, outra função exercida pelo Zé Pereira era a de reunir os foliões no Largo da Matriz para, logo depois, seguirem para o salão dos Explosivos, onde se promoviam os bailes pré-carnavalescos abertos ao público, sem uma seleção socioeconômica ou racial pré-estabelecida.

Nessas noites dançantes, os foliões tinham os primeiros contatos com as músicas que eram lançadas, na maioria das vezes, na capital ou com as marchas produzidas pelo próprio clube. "A música vinha para o clube, as partituras, e a gente ia aprender no clube. O Zé Pereira era o pré-carnaval, todo sábado antes do carnaval saía o Zé Pereira." 36

apresentação a qual se referia ao Zé Pereira como um plebeu brincalhão e inofensivo. Como a historiadora frisou, isso soou como um esforço de moldar a manifestação dentro dos arquétipos de civilização tão debatidos pelas elites intelectuais, preocupadas com o destino da nação brasileira, tomada pelos "folguedos injuriosos" do carnaval. Dessa maneira, essa paródia de Vasques sugeria um diálogo entre o humilde Zé Pereira e o modelo de carnaval polido proposto pelos intelectuais e as sociedades carnavalescas. Fato que revelava a proporção do mal-estar que abatia à sociedade carioca, que tentava entrincheirar essas manifestações "bárbaras".

${ }^{36}$ Maria da Conceição Pinto Duarte. Entrevistada por Felipe Araujo Xavier e André Colombo, nov. 2004. 
Como diria Carmelita Betonte, esses bailes pré-carnavalescos duravam poucas horas, chegando apenas à meia-noite. Assim como as horas se passavam para o término dessas festas, os anos se passaram e os clubes foram se modificando e perdendo as forças. Na década de 1970, os Explosivos e seus bailes pré-carnavalescos ainda foram recorrentes para anunciar a chegada do carnaval, mas o Zé Pereira já não fazia parte do clube.

\section{O Bloco do Zé Pereira e sua emancipação: o folguedo ressignificado e reinventado}

O carnaval da rua está por conta das Escolas de Samba, pois os clubes, segundo sabemos, não desfilaram. Veremos também os blocos folclóricos do "Zé Pereira" e das "Mulinhas". (FUNDAÇÃO CHICO BOTICÁRIO, 1979, p. 1). ${ }^{37}$

No ano de 1979, o jornal A Gazeta faz a primeira referência documental encontrada do Bloco do Zé Pereira independente de qualquer agremiação e como um bloco singular, o qual tomou status de manifestação oficial de Rio Novo, sem compartilhar espaço com outros zé-pereiras.

Tudo indica que o Bloco teria saído do clube dos Explosivos, aproximadamente nos anos 50, quando essa agremiação não comportou em seu porão a sua parafernália junto com as máquinas e equipamentos para a confecção das fantasias dos préstitos do clube.

Dona Carmelita relembra esse evento da seguinte maneira:

[...] antes do Explosivos acabar o Senhor Juquita já tinha arrumado um lugar para tirar as bonecas. Porque lá embaixo [no galpão dos Explosivos] nós costurávamos para fazer as fantasia do carnaval. Aí ele tirou as bonecas e arrumou um lugar para as bonecas, onde era [...] Canto do Sabiá, né. ${ }^{38}$

Segundo João Pinheiro, cuja infância foi permeada pela participação nas filas de meninos que carregaram as lanternas iluminando os desfiles, em meados da década de 1950, o Zé Pereira já se organizava independentemente e "[...] o Senhor Nelson tinha um galpão e guardava os bonecos nesse galpão".

\footnotetext{
${ }^{37}$ FUNDAÇÃO CHICO BOTICÁRIO. Jornais. Salve a Alegria! Viva o Carnaval. A Gazeta, Rio Novo, 24 fev. 1979. p. 1.

${ }^{38}$ Carmelita Betonte Mattos. Entrevistada por Felipe Araujo Xavier e André Colombo, ago. 2005.
} 
Eu era moleque e era uma fila (de meninos com suas lanternas na cabeça) uma do lado direito, outra no esquerdo e a banda ficava no meio e alguns, os personagens mais antigos vestidos de... a caráter, com uma casa na cabeça, tinha um tal de Tão que colocava até um cogumelo na cabeça e eu achava aquilo maravilhoso. Pelo cara ter uma ideia tão louca assim. [...] Olha e fluía, isso aí era show de bola. Uma ala não interferia na outra e era aquela musiquinha do Zé Pereira, não tinha nenhum samba, nada de marchinha. Era Zé Pereira atrás da bananeira e era isso aí o tempo inteiro, desde que saía até na volta. Era chato, mas era aquilo. ${ }^{39}$

O depoente segue afirmando que havia uma organização tão rígida que não se podia atravessar de uma fileira para a outra e os meninos, entoados pelo ritmo da música, iam marchando pelas ruas como espécies de soldados. ${ }^{40}$

Sob a organização de Senhor Juquita e seu sobrinho, Nelson Paes, esse Zé Pereira adquiria uma nova identidade, na qual o seu nome próprio serviu para mencionar somente um único cortejo rionovense, o Bloco do Zé Pereira.

Assim, paulatinamente, o cortejo foi se reordenando. A típica música do "Zé Pereira atrás da bananeira" foi novamente dividindo espaço com as marchinhas que chegavam do Rio de Janeiro, a ordem das filas dos meninos foi sendo perdida e as lanternas desaparecendo. O Bloco do Zé Pereira tomava proporções cada vez maiores, sendo composto apenas pelos foliões fantasiados, os bonecos gigantes e a banda de música.

Exatamente nesse momento, no qual a manifestação sofreu intensas transformações, iniciou-se um exercício intenso pela busca do passado desse folguedo. Dentre as principais representações sobre a origem do Zé Pereira, destaco aquela apresentada pelo Livro de Ouro de 5 de fevereiro de 1982, no qual se basearam muitas outras reconstruções da história do bloco.

Procurando arrecadar subsídio para colocar o Bloco do Zé Pereira desfilando nas ruas da cidade, o livro apresentou o seguinte resgate:

A presença deste livro foi lembrada na continuação do "zé-pereira" de Rio Novo, em 1924, quando os clubes deixaram de sair com este tradicional bloco, passando então desta época a ser um bloco independente e que vem até nossos dias atuais relembrando com saudade aqueles áureos dias do "Zépereira" que trazia e continua trazendo para nós a alegria sem partido, sem cores, sem classes e sem idades, servindo para uma colaboração espontânea de todos os cidadãos, ficando marcado no futuro estas contribuições e a presença constante do querido e tradicional "Zé-pereira", e para fazer face às despesas necessárias para manutenção deste bloco. (ACERVO PARTICULAR DA FAMÍLIA FREITAS, 1982). ${ }^{41}$

\footnotetext{
${ }^{39}$ João Pinheiro Neto. Entrevistado por Felipe Araujo Xavier, mai. 2009.

${ }^{40}$ João Pinheiro Neto. Entrevistado por Felipe Araujo Xavier, mai. 2009.

${ }^{41}$ ACERVO PARTICULAR DA FAMÍliA FREITAS. Livro de Ouro do Bloco do Zé Pereira. Rio Novo. 5 fev. 1982.
} 
Assinado por José Vieira de Freitas (Senhor Juquita) e Nelson de F. Paes, essas informações embasaram matérias jornalísticas, mas pecaram nas afirmações sobre o período no qual ocorreu o desligamento entre os clubes e os zé-pereiras.

Tendo conhecimento das atas de reuniões dos Renitentes, nas quais o próprio nome de José de Freitas está inserido como um dos sócios fundadores, se pode encontrar um cartaz no qual se anunciava o carnaval de 1926, referendando a promoção do Zé Pereira. Adicionado a isso também encontramos diversas referências de zépereiras promovidos pelo Club Explosivos Carnavalescos, posteriormente ao ano de 1924. Dessa maneira, a data de independência do bloco tende ao erro de precisão.

Mesmo assim, com a memória perdida ou camuflada nos vastos anos passados, para muitos a data de 1924 tornou-se o marco inicial desse bloco. Isso é visível quando encontramos um estandarte nas fotos do bloco, que se refere à existência do Zé Pereira de 1924 a 1983.

Essa ideia seria publicada em reportagens pela imprensa escrita, como ocorreu num periódico de circulação regional, Jornal da Região, onde encontramos uma matéria, "Rio Novo e Zé Pereira na folia", frisando a celebração de 62 anos de autonomia do bloco no ano de 1986. Adicionado a isso, nessa mesma página tivemos contatos com a primeira publicação jornalística, a qual apresentava a versão da fundação do Zé Pereira no ano de 1906.

Além da carente maneira que o jornalista apresentou o folguedo, essa matéria vem carregada de informações improváveis, como a saída desse primitivo desfile do Centro do Sabiá, bar que tem "Canto do Sabiá" como real denominação, cuja sua existência não se remonta ao ano de 1906 (ACERVO PARTICULAR DA FAMÍLIA FREITAS, [S.I.:s.n.]). ${ }^{42}$

Esse exercício de resgate dos primórdios da manifestação teve grande expressividade nos anos 80, década na qual o bloco atingiu o reconhecimento dos programas de televisão apresentados a todo país. Cientes da tradição da manifestação cultural rionovense, no final de semana que antecedia o carnaval, representantes de emissoras de televisão visitavam a pacata cidade para levar as imagens de sua folia aos seus programas. A Rede Globo, por exemplo, chegou a dar espaço especial ao Zé Pereira, apresentando o bloco no programa "Fantástico". Talvez isso tenha ajudado a

\footnotetext{
${ }^{42}$ ACERVO PARTICULAR DA FAMÍLIA FREITAS. Jornal da Região. [S.I.:s.n.].
} 
instigar essa busca pelo passado do bloco, gerando uma gama de representações sobre suas origens.

Muitos anos se passaram, a "revolução da informação" acarretada pela internet já estava consolidada e o trabalho de resgate histórico não cessou. Seguindo a datação apresentada pelas memórias do Senhor Juquita, no ano de 2006, foi comemorado o centenário do Zé Pereira e, como um dos eventos de solenidade, foi produzido um documentário no qual se trabalhou o passado da folgança em Rio Novo, quase como uma reafirmação do "discurso oficial".

Logo nesse contexto, me deparei com uma nova versão da origem do Zé Pereira, apresentada pelos antigos foliões do Club dos Explosivos Carnavalescos. Em entrevista, Maria Pinto repete várias vezes que a fundação desse bloco teria sido dentro dos Explosivos e que essa folgança sempre estive ligada a esse clube até seu fechamento.

\begin{abstract}
Onde era os Explosivos hoje é o Porão. Só que ali era completamente diferente. Era uma casa antiga, baixinha, tinha umas oito janelas. Os Explosivos era baixinho, tanto que nos bailes as pessoas que ficavam do lado de fora, que não entravam no salão, debruçavam na janela para assistir os bailes dos Explosivos. Tinha uma varanda assim ao lado e os Explosivos ficavam na direção da rua, no mesmo nível. Embaixo tinha um porão enorme, neste porão é que faziam as lanternas. Quando acabava o carnaval, guardava tudo ali no porão. Se quisesse restaurar, restauravam; se quisessem fazer novos bonecos, fazia, tudo aqui nos Explosivos. Tanto quando o Nelson e o Senhor Juquita reviveu o Zé Pereira, foi lá também. Nunca houve outro Zé Pereira, esse foi fundado em 1907 junto com os Explosivos. ${ }^{43}$
\end{abstract}

Seja como for, o bloco nos anos 80 já não se assemelhava mais às características do polido Zé Pereira formado e organizado pelo Club Explosivos Carnavalescos. O Bloco do Zé Pereira, dirigido pelo Senhor Juquita e Nelson Paes, tomou identidade própria, caracterizado pelo seu espírito aglutinador com proporções cada vez maiores.

Inicialmente, conseguiram manter o rígido ordenamento no cortejo, mas o policiamento dos comportamentos foi diminuindo e os excessos paulatinamente ganharam espaço, trazendo, muitas vezes, um clima de confusão à manifestação. Continuaram com seus bonecos gigantes ${ }^{44}$, uma banda, a Euterpe Carlos Gomes, regendo as músicas entre as quais ainda destacava-se a velha troça: "Viva o Zé Pereira / Atrás da bananeira / Comeu muita banana / e ficou de caganeira”.

Portanto, nessa fase de autonomia do folguedo, no qual o próprio carnaval encontrava-se em reordenação, deparo com diversos pontos de reformulação e

\footnotetext{
${ }^{43}$ Maria da Conceição Pinto Duarte. Entrevistada por Felipe Araujo Xavier e André Colombo, nov. 2004.

${ }^{44}$ Maria da Conceição Pinto Duarte. Entrevistada por Felipe Araujo Xavier e André Colombo, nov. 2004.
} 
ressignificação do Zé Pereira. Mesmo assim, o bloco passou a representar a manutenção do passado carnavalesco da cidade, em meio ao surgimento de um novo carnaval rionovense no qual as Escolas de Samba tornavam-se hegemônicas e os clubes já não colocavam seus préstitos nas ruas.

Por isso, para retomar os primórdios do carnaval de Rio Novo, antes é necessário ter a sensibilidade de escutar e sentir a presença da zabumba e do grito do "Zé Pereira". Pois foi assim que os zé-pereiras anunciaram os carnavais dos clubes carnavalescos e abriram alas para as Escolas de Sambas e muitos outros blocos rionovenses.

\section{Considerações finais}

Em um artigo no qual se almeja fazer um estudo histórico de quase todo o século XX para poder captar as diferentes formas de organização dos zé-pereiras em Rio Novo e, tangencialmente, retratar aspectos socioculturais desse patrimônio histórico rionovense, depara-se com vários desafios. Dentre esses, enfrentar a tensão entre abordar o fenômeno carnavalesco na longa duração e, ao mesmo tempo, dar conta das particularidades dos eventos, os quais ocorrem dentro de uma curta temporalidade específica.

A partir desse ponto, procurei retratar suas modificações estruturais, permeadas pela reordenação dos significados inseridos nesse tipo de folguedo. De sua origem lusitana à inserção do Zé Pereira nas folganças cariocas do século XIX, resgato os modelos os quais influenciaram os zé-pereiras de Rio Novo e as diferentes formas as quais esses folguedos foram organizados.

Entretanto, nos anos de 1950, essa pluralidade de modelos foi desaparecendo na cidade, para dar lugar a apenas um, o Bloco do Zé Pereira. Esse bloco carregou consigo uma diversidade de significados entrepostos pelas representações das memórias, documentos e registros.

Para alguns, esse Bloco do Zé Pereira apresentava-se como uma simples continuação do folguedo dos Explosivos, para outros, sua história está atrelada ao evento do desfile dos foliões com o carro de boi, batendo suas latas.

Seja como for, aqui o Zé Pereira passou por um processo de modificações as quais o tornou cada vez mais popular e de proporções nunca antes atingidas, sendo reconhecido pelos meios de comunicação de massa. 
Naquele contexto, a manifestação cultural já sofria de uma relativa perda de sua memória, gerando um conflito simbólico interpretativo de reconstrução das suas origens e trazendo um exercício de reinvenção da tradição pelos documentos e pelas memórias dos foliões.

Assim, o resgate do seu passado se tornou-se um chamado social e pessoal, o qual impulsionou o Zé Pereira a se tornar o primeiro "patrimônio imaterial" ou “intangível” registrado na pequena cidade de Rio Novo, o que viabilizou a manutenção e fortalecimento dessa manifestação cultural rionovense tão viva e dinâmica. 


\section{REFERÊNCIAS}

\section{Fontes primárias}

ACERVO PARTICULAR DA FAMÍLIA FREITAS. Livro de Ouro do Bloco do Zé Pereira. Rio Novo. Fev. 1982.

ACERVO PARTICULAR DA FAMÍLIA FREITAS. Jornal da Região. [S.I.:s.n.]

FAZENDA, Vieira. Antiqualhas e memórias do Rio de Janeiro. Rio de Janeiro: Revista do IHGB, 1940.

FUNDAÇÃO CHICO BOTICÁRIO. Jornais. Formação Administrativa. O Anuário d'A Gazeta, Rio Novo, dez. 1951.

FUNDAÇÃO CHICO BOTICÁRIO. Jornais. Farpinhas. O Rio Novo, Rio Novo, 3 fev. 1907. p. 1.

FUNDAÇÃO CHICO BOTICÁRIO. Jornais. Carnaval. O Rio Novo, Rio Novo, 26 jan. 1908.

FUNDAÇÃO CHICO BOTICÁRIO. Jornais. Renitentes. O Paládio, Rio Novo, 27 dez. 1925.

FUNDAÇÃO CHICO BOTICÁRIO. Jornais. Os Zé Pereiras. O Explosivo, Rio Novo, 8 mar. 1928. p. 1.

FUNDAÇÃO CHICO BOTICÁRIO. Jornais. Carnaval. Gazeta Rionovense, Rio Novo, jan. 1933.

FUNDAÇÃO CHICO BOTICÁRIO. Jornais. Carnaval. A cidade está inteiramente tomada por intensa alegria. A Gazeta, Rio Novo, 2 mar. 1946. p.1.

FUNDAÇÃO CHICO BOTICÁRIO. Jornais. Salve a Alegria! Viva o Carnaval. A Gazeta, Rio Novo, 24 fev. 1979. p. 1.

PAVEL, Benjamim. Besta de Sela. Memórias Romanceadas. Rio de Janeiro: Editora Pongetti, 1965.

\section{Fontes secundárias}

BOSI, Ecléa. Memória e sociedade: lembrança de velhos. São Paulo: Companhia das Letras, 1994.

CARMO, Brenildo Ayres do. Na mesma Praça. História, fatos e lembranças. História e cultura dos Sertões do Leste. Revista Chico Boticário, Rio Novo, p. 30-37, jan. 2006.

CUNHA, Maria Pereira Clementina da. Ecos da Folia: uma história social do Carnaval Carioca entre 1880 e 1920. São Paulo: Companhia das Letras, 2001. 
CUNHA, Maria Pereira Clementina da. Carnavais e outras f(r)estas: ensaios de história social da cultura. Campinas: Editora da Unicamp; Cecult, 2002.

DA MATTA, Roberto. Carnavais malandros e heróis: para uma sociologia do dilema brasileiro. Rio de Janeiro: Zahar, 1981.

EDMUNDO, Luís. O Rio de Janeiro do meu tempo. Brasília: Senado Federal, 2003.

FONSECA, Maria Cecília Londres. Para além da pedra e cal: por uma concepção ampla de patrimônio cultural. In: ABREU, Regina; CHAGAS, Mario (Org.). Memória e patrimônio: ensaios contemporâneos. Rio de Janeira: DP\&A, 2003.

FERNANDES, Tania Maria. Edição de entrevista: de linguagem falada à escrita. In: MONTENEGRO, Antônio Torres; FERNANDES, Tania Maria (Org.). História oral: um espaço plural. Recife: Universitária, 2001. p. 91-98.

ROUSSO, Henry. A memória não é mais o que era. In: AMADO, Janaína; FERREIRA, Marieta de Moraes (Org.). Usos e abusos da história oral. Rio de Janeiro: Editora FGV, 2002. p. 93-101.

SOIHET, Rachel. A Subversão pelo Riso: estudos sobre o carnaval carioca da Belle Époque ao tempo de Vargas. Rachel Soihet. Rio de Janeiro: Editora Fundação Getúlio Vargas, 1998. 